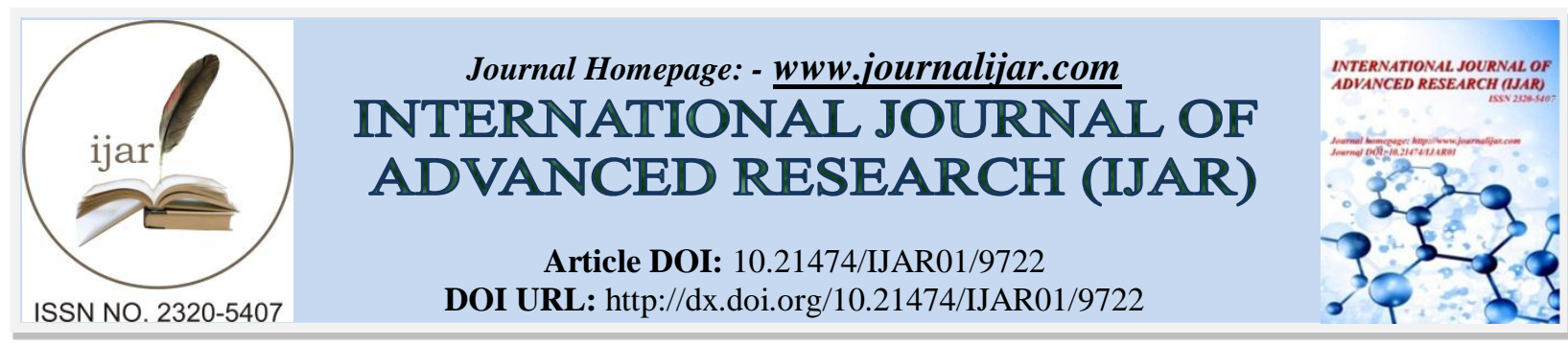

RESEARCH ARTICLE

\title{
EFFECT OF AZADIRACHTA INDICA A.JUSS. AND GYNURA PROCUMBENS (MERR.) LEAF EXTRACT COMBINATION TOWARDS FREE-RADICAL SCAVENGING ACTIVITY.
}

Nofran Putra Pratama, Kurnia Rahayu Purnomo Sari and Ema Mutya.

Pharmacy Study Program (S-1) Faculty of Health, Jenderal Achmad Yani University, Yogyakarta, Indonesia.

\section{Manuscript Info}

Manuscript History

Received: 09 July 2019

Final Accepted: 12 August 2019

Published: September 2019

Key words:-

Azadirachta indica A.Juss, Gynura procumbens (Merr.), antioxidant, DPPH.

\section{Abstract}

Introduction: The use of traditional medicine in Indonesia, especially those of herbal origin, is growing in response to the increasing price of the conventional medicine and the limited purchasing ability of the society. Extracted leaves from plants such as Azadirachta indica A.Juss. and Gynura procumbens (Merr.) are examples of herbal medicine. The combination of both extract has the potential to be an antihyperglycemic agent through exploitation of its antioxidant properties.

Aims \& Objectives: This study focuses on testing the antioxidant activity of of a combination of ethanol extract Azadirachta indica A.Juss. and Gynura procumbens (Merr.) by in vitro.

Material \& Methods: Antioxidant activity is tested using free radical DPPH (1,1-diphenyl-2-picrylhydrazyl) reduction method in comparison to vitamin $\mathrm{C}$. The resulting antioxidant activity level of strength is determined based on $\mathrm{IC}_{50}$ values obtained.

Results: antioxidant activity test showed that Azadirachta indica A.Juss. and Gynura procumbens (Merr.) ethanol extract combination of 75:25 has the best $\mathrm{IC}_{50}$ value of $67.407 \mu \mathrm{g} / \mathrm{mL}$, while the $50: 50$ and 25:75 ethanol extract combination has $\mathrm{IC}_{50}$ value of $68.864 \mu \mathrm{g} / \mathrm{mL}$ and $102.887 \mu \mathrm{g} / \mathrm{mL}$ respectively.

Discussion: The three combinations are weaker in comparison to the standard vitamin $\mathrm{C}$ antioxidant activity with $\mathrm{IC}_{50}$ value of 3.546 $\mathrm{mg} / \mathrm{mL}$. Statistical analysis using one-way ANOVA concludes significant difference in antioxidant activity of all three comparing groups.

Conclusions: Gynura procumbens (Merr.) and Gynura procumbens (Merr.) extract combination of 75:25 has strong category antioxidant activity.

Copy Right, IJAR, 2019,. All rights reserved.

\section{Introduction:-}

Free radicals are compounds or molecules that contain one or more unpaired electrons in their outer orbitals. The existence of unpaired electrons causes the compound to be very reactive looking for pairs by attacking the electrons of molecules around them (Pratama dkk., 2018). However, antioxidant compounds can inhibit the reactivity of free radicals by stabilizing it (Winarsih, 2007).

Corresponding Author:-Nofran Putra Pratama.

Address:-Pharmacy Study Program (S-1) Faculty of Health, Jenderal Achmad Yani University, 
Antioxidant intake is important for all age groups be it children or even adults. Consumption of antioxidants in sufficient amounts reportedly able to reduce degenerative disease occurrences (Winarsi, 2007). Leaf of both Azadirachta indica A. Juss. and (Gynura procumbens (Merr) plants are widely reported to be the source of antioxidant.

Both plants are rich of phenolic compounds, polyphenols, flavonoids, coumarin, quercetin, routine, and tannins (Denardi et al., 2010; Biswas et al., 2002; Sudarsono et al. 2002). The main compounds responsible for antioxidant activity are tannins, alkaloids (Alfarabi et al., 2010), and phenolic components such as phenolic terpenes, phenolic acids, and flavonoids (Javanmardi et al., 2003).

Research conducted by Sunnarwidhi (2014) reports that ethanol extract combination of Azadirachta indica A. Juss and Gynura procumbens (Merr.) containing quercetin and routine have greater effect in reducing blood sugar level compare to that of each single extract. Antioxidant administering on patients with degenerative diseases such as diabetes mellitus inhibits the formation of free radicals, reducing oxidative stress and reducing the expression of TNF- $\alpha$ (Widowati, 2010).

Based on the aforementioned facts and supported by previous research on the presence of active compounds acted as antioxidants, it is necessary to conduct research to test the antioxidant activity in ethanol extract combination of Azadirachta indica A. Juss and Gynura procumbens (Merr.). Furthermore, it deepens the information regarding the efficacy of this extract combination compare to that of each single extract.

\section{Aims \& objectives:-}

Understanding the combined activity of Azadirachta indica A. Juss (M) and Gynura procumbens (Merr.) ethanol extract as antioxidant through free-radical DPPH scavenging Method.

\section{Material \& methods:-}

The main tools used in this study namely: rotary evaporator (IKA ${ }^{\circledR}$ RV8), UV-Vis spectrophotometer (Genesys ${ }^{\circledR}$ 10S) and a micropipette (Eppendorf ${ }^{\circledR}$ Research plus). Materials used are leaf extracts of Azadirachta indica A. Juss. and Gynura procumbens (Merr) obtained from Moyudan Sleman, Yogyakarta, and also $70 \%$ ethanol (technical). Materials for the antioxidant activity test is a standard vitamin C (Sigma Chemicals Co.), DPPH (2,2-diphenyl-1picrylhydrazyl) from Sigma Chemicals Co. and methanol pro analysis from E. Merck.

\section{Course of Study:}

Test to examine the potency of ethanol extract combination toward free radical DPPH scavenging activity, carried out in three series of combination between Azadirachta indica A. Juss. and Gynura procumbens (Merr), respectively 25:75; 50:50; 75:25. Then, 1,000-ppm test liquid was diluted into concentrations of 300 ppm, 250 ppm, 200 ppm, $150 \mathrm{ppm}, 100 \mathrm{ppm}$ and $50 \mathrm{ppm}$ using $5 \mathrm{~mL}$ volumetric. Vitamin C solutions of 5-ppm concentration; 10-ppm; 15ppm; 20-ppm; 25-ppm and 30-ppm acted as positive control. Each solution was then reacted with DPPH and incubated for 30 minutes. Absorption reading is determined using a UV-Vis spectrophotometer at a maximum wavelength of $516 \mathrm{~nm}$. Scavenging DPPH free radical activity by Azadirachta indica A. Juss. and Gynura procumbens (Merr) extract combination is calculated as \%inhibition and then expressed in $\mathrm{IC}_{50}$ value. The value indicates amount of concentration required for the test sample to capture $50 \%$ of DPPH free radical.

\section{Statistical Analysis:-}

Statistical analysis using one-way ANOVA obtains significant different in antioxidant activity among all three comparison groups.

\section{Result:-}

Organoleptic testing has an important role in applying quality of a product. Organoleptic testing can provide indications of decay, deterioration or damage to quality. The organoleptic extract results obtained shown in Table 1.

Table 1:-Extract Identity and Organoleptic Extract Test Results

\begin{tabular}{|l|l|l|}
\hline Parameter & & \\
\hline $\begin{array}{l}\text { Extract Identity } \\
\text { extrack }\end{array}$ & Ethanol extract of Azadirachta & Ethanol extract of Gynura \\
\hline
\end{tabular}




\begin{tabular}{|l|l|l|}
\hline $\begin{array}{l}\text { Name of origin plant } \\
\text { Parts used }\end{array}$ & $\begin{array}{l}\text { indica A. Juss } \\
\text { Azadirachta indica A. Juss } \\
\text { Leaf }\end{array}$ & $\begin{array}{l}\text { procumbens } \text { (Merr.) } \\
\text { Gynura procumbens } \text { (Merr.) } \\
\text { Leaf }\end{array}$ \\
Organoleptic Extract Test & & \\
Color & Blackish green \\
$\begin{array}{l}\text { Odor } \\
\text { consistency }\end{array}$ & Aromatic typical \\
Taste & Thick & $\begin{array}{l}\text { Blackish green } \\
\text { Aromatic typical } \\
\text { Thick }\end{array}$ \\
\hline
\end{tabular}

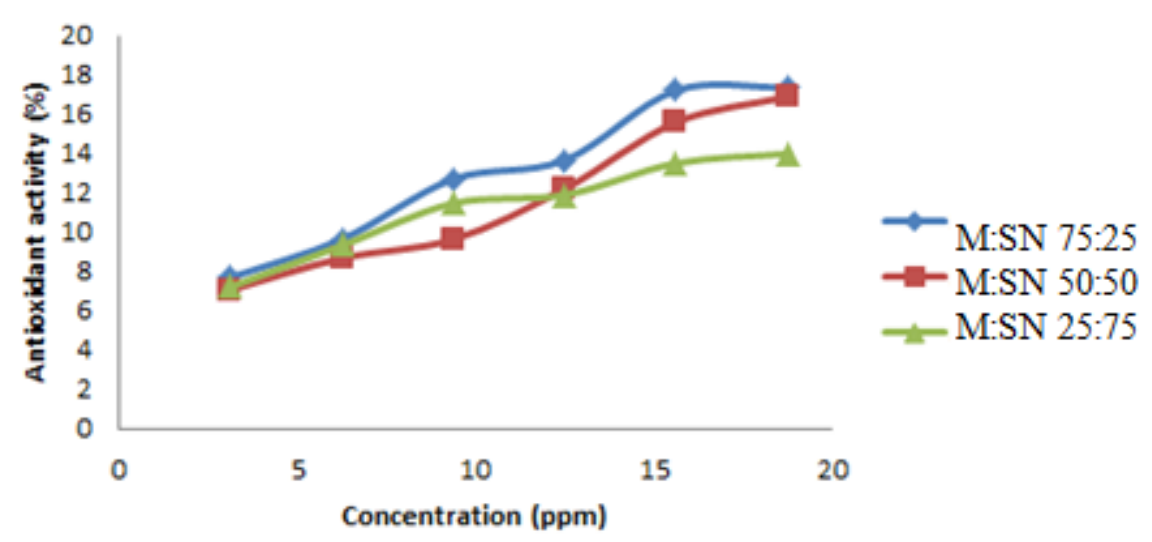

Figure 1:-Relationship between the ethanol extract combination of Azadirachta indica A. Juss (M) and Gynura procumbens (Merr.) (SN) and Antioxidant Activity Percentage

The result of the antioxidant activity test for 75:25 combination between Azadirachta indica A. Juss and Gynura procumbens (Merr.) extract has an $\mathrm{IC}_{50}$ value of $67.407 \mu \mathrm{g} / \mathrm{mL}$, while the combination of 50:50 has an $\mathrm{IC}_{50}$ value of $68.864 \mu \mathrm{g} / \mathrm{mL}$. These two combination ratios of 75:25 and 50:50 considered as powerful antioxidants. On the other hand, the 25:75 ratio combination had an $\mathrm{IC}_{50}$ value of $102,887 \mu \mathrm{g} / \mathrm{mL}$ hence considered a moderate antioxidant. All three combination-groups had weaker antioxidant activity compared to standard vitamin $\mathrm{C} \mathrm{IC}_{50}$ value of 3.546 $\mu \mathrm{g} / \mathrm{mL}$.

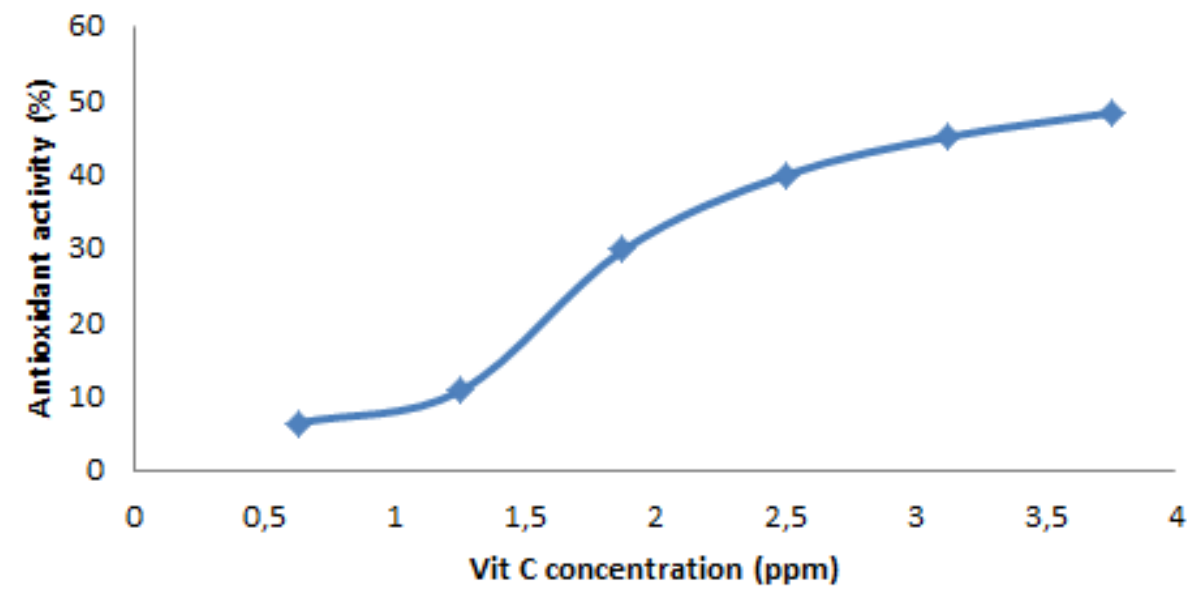

Figure 2:-Graphical relation between Vitamin C Concentration and Antioxidant Activity Percentage

Table 2:-IC $\mathrm{IC}_{50}$ Values of Vitamin C, M: SN (75:25) Combination Extract, M: SN (50:50) Combination Extract, and M: SN (25:75) Combination Extract

\begin{tabular}{|l|l|l|}
\hline Sample & $\mathrm{IC}_{50}(\mu \mathrm{g} / \mathrm{mL})$ & The level of antioxidant activity with the DPPH method \\
\hline
\end{tabular}




\begin{tabular}{|c|c|c|c|c|c|}
\hline & & $\begin{array}{l}\text { Very Strong } \\
\left(\mathrm{IC}_{\mathbf{5 0}}<\mathbf{5 0}\right. \\
\boldsymbol{\mu g} / \mathbf{m L})\end{array}$ & $\begin{array}{l}\text { Strong }(\text { IC50 } \\
50-100 \mu \mathrm{g} / \mathrm{mL})\end{array}$ & $\begin{array}{l}\text { Moderate (IC50 } \\
101-150 \mu \mathrm{g} / \mathrm{mL})\end{array}$ & $\begin{array}{l}\text { Weak (IC50>150 } \\
\mu \mathrm{g} / \mathrm{mL})\end{array}$ \\
\hline $\begin{array}{l}\text { Vit C } \\
\text { M:SN 75:25 } \\
\text { M:SN 50:50 } \\
\text { M:SN 25:75 }\end{array}$ & $\begin{array}{l}3,546 \\
67,407 \\
68,864 \\
102,887\end{array}$ & $\sqrt{ }$ & $\begin{array}{l}\sqrt{ } \\
\sqrt{ }\end{array}$ & $\sqrt{ }$ & \\
\hline
\end{tabular}

\section{Discussions:-}

The results of antioxidant activity test between ethanol extract combination of Azadirachta indica A. Juss and Gynura procumbens (Merr.) and the Vitamin C standard expressed in percent reduction using free radical DPPH scavenging method then plotted against the concentration to obtain linear regression equation. DPPH solution uptake is measured at maximum wavelength using a spectrophotometer. The maximum wavelength obtained is $516 \mathrm{~nm}$. This wavelength corresponds to DPPH wavelengths ranging from 515 - $520 \mathrm{~nm}$ (Molyneux, P., 2004).

The result of the antioxidant activity test between ethanol extract combination of Azadirachta indica A. Juss and Gynura procumbens (Merr.) with a ratio of 75:25 has an $\mathrm{IC}_{50}$ value of 67.407 . Hence, it is included in the category of strong antioxidants. $\mathrm{IC}_{50} 67.407 \mu \mathrm{g} / \mathrm{mL}$ indicates that the concentration required for $75: 25$ ethanol extract combination of Azadirachta indica A. Juss and Gynura procumbens (Merr.) to inhibit 50\% of DPPH radical is $67.407 \mu \mathrm{g} / \mathrm{mL}$. Result of the antioxidant activity test between ethanol extract combination of Azadirachta indica A. Juss and Gynura procumbens (Merr.) with a ratio of 50:50 has an $\mathrm{IC}_{50}$ value of $68.864 \mu \mathrm{g} / \mathrm{mL}$ and also among the category of strong antioxidants. $\mathrm{IC}_{50} 68,864 \mu \mathrm{g} / \mathrm{mL}$ indicates that the concentration required for 50:50 ethanol extract combination of Azadirachta indica A. Juss and Gynura procumbens (Merr.) to inhibit 50\% of DPPH radical is $68.864 \mu \mathrm{g} / \mathrm{mL}$. Result of the antioxidant activity test between ethanol extract combination of Azadirachta indica A. Juss and Gynura procumbens (Merr.) with a ratio of $25: 75$ has an $\mathrm{IC}_{50}$ value of $102.887 \mu \mathrm{g} / \mathrm{mL}$. It is considered moderate antioxidants. $\mathrm{IC}_{50} 102,887 \mu \mathrm{g} / \mathrm{mL}$ indicates that the concentration required for $25: 75$ ethanol extract combination of Azadirachta indica A. Juss and Gynura procumbens (Merr.) to inhibit 50\% of DPPH radicals is $102,887 \mu \mathrm{g} / \mathrm{mL}$ (Molyneux, P., 2004).

Based on the antioxidant activity test of the sample (Table 2), the 75:25 ethanol extract combination between Azadirachta indica A. Juss and Gynura procumbens (Merr.) has a relatively stronger antioxidant activity compared to the 50:50 and 25:75 ratio combination. The 25:75 combination has the weakest antioxidant activity. All three combination-groups had weaker antioxidant activity compared to $\mathrm{IC}_{50}$ standard vitamin $\mathrm{C}$ that has an $\mathrm{IC}_{50}$ of 53,546 $\mu \mathrm{g} / \mathrm{mL}$.

SPSS statistical analysis test using one-way ANOVA with 95\% confidence level indicating significant value (p $<0.05$ ). Hence, there is a significant difference in the antioxidant activity between each ethanol extract combination of Azadirachta indica A. Juss and Gynura procumbens (Merr.) with respective ratio of 75:25, 50:50, and 25:75. Combined antioxidant activity depends not only on concentration, but also on the structure of antioxidant compounds. The antioxidant activity of plant extracts is usually associated with phenol groups in these plants. Both Azadirachta indica A. Juss and Gynura procumbens (Merr.) leaf has many flavonoids containing hydroxyl (OH) groups. Hydrogen atoms in both extracts can be detached and captured by DPPH radical. It then stabilize DPPH radical to be a non-radical.

\section{Conclusions:-}

Ethanol extract combination between Azadirachta indica A. Juss and Gynura procumbens (Merr.) has the best antioxidant activity at a ratio of $75: 25$ with an $\mathrm{IC}_{50}$ value of $67.407 \mu \mathrm{g} / \mathrm{mL}$.

\section{Reference:-}

1. Alfarabi, M., Bintang, M., Suryani., \& Safithri, M., 2010, The Comparative Ability of Antioxidant Activity of Piper crocatum in Inhibiting Fatty Acid Oxidation and Free Radical Scavenging, Hayati Journal of Biosciences, 17 (4), 201-204.

2. Biswas, K., Chattopadhyay, I., Banerjee, R. K\& Bandyopadhyay, U., 2002, Biological Activities and Medicinal Properties of (Azadirachta indica),Curr. Sc., $82: 1336-1345$. 
3. Denardi, S. E., Bechara, G. H., Oliveira, P. R \& Camargo-Mathias, M. I., 2010, Azadirachta indica A. Juss Induced Morphological Changeson Oocytes of Rhipicephalus sanguineus (Latreille, 1806) (Acari:Ixodidae) tick females, Exp Parasitol, 126(4): 462-470

4. Javanmardi, J., Stushnoff, C., Locke, E., \& Vivanco, J.M., 2003, Antioxidant Activity and Total Phenolic Content of Irian Ocimun Accession, J. Food Chem, 83, 547-50.

5. Molyneux, P., 2004, The Use of Stable Free Radical Diphenylpicryl-hydrazyl (DPPH) for Estimating Antioxidant Activitiy, 26 (2) : 211-219.

6. Pratama, N.P., Purnomo, K.R., Mutya, E. 2018, Uji Aktivitas Kombinasi Ekstrak Etanol Azadirachta indica A. Juss. Dan Gynura procumbens (Merr.) Sebagai Antioksidan Dengan Metode Peredaman Radikal Bebas DPPH, Penelitian Dosen, Fakultas Kesehatan, Universitas Jenderal Achmad Yani, Yogyakarta.

7. Sudarsono, Gunawan, D., Wahyuono, S., Donatus, I.A., dan Purnomo, 2002, Tumbuhan Obat II, Hasil Penelitian, Sifat-sifat dan Penggunaan, 96-100, Pusat Studi Obat Tradisional, Universitas Gadjah Mada, Yogyakarta.

8. Sunarwidhi, Anggit., 2014, Efek Hipoglikemik Kombinasi Ekstrak Larut Etanol Daun Mimba (Azadirachta indica a. juss.) dan Daun Sambung Nyawa (Gynura procumbens (Merr.)) Terstandar Rutin dan Kuersetin pada Tikus Diabetes Terinduksi Aloksan, Tesis, M.Sc, Fakultas Farmasi Universitas Gadjah Mada, Yogyakarta.

9. Widowati, W. 2010, Potensi Antioksidan sebagai Antidiabetes, Jurnal Kedokteran Maranatha, 7.

10. Winarsi H., 2007, Antioksidan Alami dan Radikal Bebas, Penerbit Kanisius, Yogyakarta. 